\title{
Efektifitas Simulasi Resusitasi Jantung Paru Terhadap Kemampuan Pe- natalaksanaan Resusitasi Jantung Paru Anggota Brimob
}

\author{
Prima Dewi Kusumawati ${ }^{1}$, Adetya Wahyu Dwi Jaya ${ }^{2}$ \\ 1,2,Stikes Mitra Husada Kediri Indonesia \\ Jl. Manila, No. 37, Sumberece, Tosaren, Kec. Pesantren, Kota Kediri, Jawa Timur 64133 \\ Email: prima.lppmstrada@gmail.com ${ }^{1}$, Adetyawahyu@ strada.ac.id ${ }^{2}$,
}

\begin{abstract}
Abstrak
Pendahuluan: Kurangnya kemampuan masyarakat dalam melakukan pertolongan pertama pada korban yang mengalami henti jantung disebabkan karena masih kurang pengetahuan yang dimiliki masyarakat khususnya tentang cara melakukan resuistasi jantung paru sehingga angka kematian akibat henti jantung meningkat.

Tujuan: mengetahui tingkat efektifitas simulasi resusitasi jantung paru terhadap kemampuan penatalaksanaan resusitasi jantung paru Anggota Brimob

Metode: desain penelitian adalah pra eksperimental dengan pendekatan one-group pre test post test. Responden. Populasi semua anggota Brimob di Kompi 1 Batalyon C Pelopor Satbrimob Polda Jatim sebanyak 100 orang, dengan teknik accidental sampling didaptkan sampel sebanyak 25 responden.

Hasil: penelitian menunjukan seluruh Anggota Brimob memiliki kemampuan dengan kategori kurang terampil dalam melakukan resusitasi jantung paru sebelum dilakukan simulasi yaitu sebanyak 25 (100\%) responden, Hampir seluruh Anggota Brimob memiliki kemampuan dengan kategori terampil dalam melakukan resusitasi jantung paru setelah dilakukan simulasi yaitu sebanyak $22(88,0 \%)$. Hasil analisis data menunjukan bahwa tingkat signifikansi nilai $p=0,000$ sehingga $\mathrm{H} 1$ diterima.
\end{abstract}

Kesimpulan: ada pengartuh simulasi Resusitasi Jantung Paru terhadap kemampuan penatalaksanaan Resusitasi Jantung Paru (RJP) Anggota Brimob di Kompi 1 Batalyon C Pelopor Satbrimob Polda Jatim. Ketrampilan seseorang perlu diasah agar semakin trampil dalam melakukan bantuan hidup dasar bagi Anggota Brimob. Dengan diberikannya simulasi anggota brimob bukan hanya mendengar tetapi juga dapat melihat secara langsung tindakan yang dapat dilakukan ketika menemukan korban dengan henti jantung.

Kata Kunci: Simulasi, Kemampuan, Resusitasi Jantung Paru

\begin{abstract}
Introduction: Lack of community's ability to do first aid to victims who experience cardiac arrest is due to the short of knowledge that is owned by the community, especially about how to perform lung heart resuscitation so that the death rate due to cardiac arrest increases.

Objective: The aim of the study was to determine the effectiveness of the simulation of pulmonary resuscitation on the ability to manage pulmonary resuscitation in Brigade Mobile Members.

Method: The study design was pre-experimental with a one-group pre post test approach. Respondents were taken by accidental sampling technique. The population of all members of Brigade Mobile in Company 1 Battalion C Pioneer of Brigade Mobile Unit of Regional Police East Java as many as 100 people, a sample of 25 respondents.

Result: The results showed that all Brigade Mobile Members had the ability with the category of less skilled in performing pulmonary resuscitation before simulating 25 (100\%) Respondents, almost all Brigade Mobile members had the ability with skilled categories in performing cardiac pulmonary resuscitation after simulation, which was 22 (88.0\%). The results of data analysis showed that the significance level of p-value $=0,000$.

Conclusion: there was an effect on the simulation of Pulmonary Resuscitation on the ability to manage Pulmonary Resuscitation (RJP) of Brigade Mobile Members in Company 1 Battalion C Pioneer of Brigade Mobile Unit of East Java Regional Police. The more often simulations are carried out, the more skilled is the ability of Brigade Mobile members to carry out basic life support, because by providing simulations Brigade Mobile members not only can hear but also see firsthand the actions that can be taken when finding victims with cardiac arrest.
\end{abstract}

Keywords: simulation, ability, pulmonary resuscitation 


\section{Pendahuluan}

Salah satu kondisi kegawatdaruratan yang dapat mengancam jiwa dan membutuhkan penanganan segera adalah cardiacarrest atau henti jantung. ${ }^{1}$ Kondisi kegawatdaruratan henti jantung dapat terjadi dimana saja dan kapan saja. Salah satu tugas petugas kesehatan adalah menangani masalah tersebut. Walaupun begitu tidak menutup kemungkinan kondisi kegawatdaruratan tersebut dapat terjadi di luar rumah sakit atau di daerah yang sulit dijangkau oleh petugas kesehatan sehingga peran serta petugas keamanan seperti satuan brimob menjadi hal penting yang dibutuhkan dalam kondisi tersebut karena brimob merupakan petugas keamanan yang selalu berada di masyarakat ketika terjadi suatu peristiwa yang berbahaya ataupun ketika terjadi suatu bencana sehingga brimob dapat membantu korban yang mengalami henti jantung sebelum ditemukan oleh petugas kesehatan, oleh sebab itu satuan brimob harus memiliki pengetahuan dan kemampuan yang cukup untuk menangani korban yang mengalami henti jantung.

Sebagian besar kejadian henti jantungterjadi di luar rumah sakit. Out of Hospital Cardiac Arrest (OHCA) merupakan kejadian henti jantung mekanis yang ditandai dengan tidak adanya tandatanda sirkulasi dan terjadi di luar rumah sakit. Salah satu penyebab utama kematian dikalangan orang dewasa di Amerikan Serikat adalah OHCA dengan jumlah kejadian mencapai sekitar 300.000 setiap tahun dan sekitar $92 \%$ orang meninggal karena OHCA. ${ }^{3}$ Di Indonesia sendiri belum didapatkan data yang jelas mengenai jumlah prevalensi kejadian henti jantung di kehidupan seharihari atau di luar rumah sakit, namun diperkirakan sekitar 10.000 warga per tahun yang berarti 30 orang per hari mengalami henti jantung. Kejadian terbanyak dialami oleh penderita jantung koroner. Kematian yang disebabkan oleh penyakit jantung pembuluh darah, terutama penyakit jantung koroner dan stroke diperkirakan akan terus meningkat mencapai 23,3 juta kematian pada tahun 2030(3) Sedangkan kejadian henti jantung di Provinsi Jawa Timur sebesar 0,09\%.
Kepolisian Negara Republik Indonesia atau yang sering disingkat dengan Polri dalam kaitannya dengan Pemerintahan adalah salah satu fungsi pemerintahan negara di bidang pemeliharaan keamanan dan ketertiban masyarakat, penegakan hukum, perlindungan, pengayoman, dan pelayanan kepada masyarakat, yang bertujuan untuk mewujudkan keamanan dalam negeri yang meliputi terpeliharanya keamanan dan ketertiban masyarakat, tertib dan tegaknya hukum, terselenggranya perlindungan, pengayoman, dan pelayanan kepada masyarakat, serta terbinanya ketentraman masyarakat dengan menjunjung tinggi hak azasi manusia.

Berdasarkan Pasal 2 Undang-undang Nomor 2 Tahun 2002 tentang Kepolisian Negara Republik Indonesia (selanjutnya disingkat UU No. 2 Tahun 2002), maka fungsi kepolisian adalah salah satu fungsi pemerintahan negara di bidang pemeliharaan keamanan dan ketertiban masyarakat, penegakan hukum, perlindungan, pengayoman, dan pelayanan kepada masyarakat.

Dalam menjalankan fungsi dan perannya brimob rentan menemui kasus kegawatdarutan yang memerlukan tindakan bantuan hidup dasar, karena ketika terjadi suatu bencana brimob selalu turut ambil bagian dalam memberikan bantuan, sehingga brimob perlu memiliki kemampuan dalam memberikan bantuan hidup dasar. Minimnya pelatihan dalam hal kesehatan membuat anggota brimob enggan untuk melakukan tindakan bantuan hidup dasar, dan jika ada yang berani melakukan tindakan Resusitasi Jantung Paru (RJP) itu pun tidak sesuai dengan prosedur Resusitasi Jantung Paru (RJP). Oleh sebab itu anggota brimob perlu memiliki pengetahuan dan kemampuan yang baik dalam menangani korban henti jantung sehingga dapat membantu menyelamatkan nyawa korban yang mengalami henti jantung.

Kasus henti jantung dapat terjadi dimanapun, di masyarakat, di luar rumah sakit maupun di dalam rumah sakit. Kemungkinan bertahan hidup pada penderita henti jantung di luar rumah sakit atau pre- 
hospital menurun 7-10\% tiap menit sejak dimulainya henti jantung.

Pertolongan yang tepat dalam menangani kasus kegawatdaruratan dalam hal ini yaitu cardiac arrest adalah Basic Life Support atau yang dikenal dengan Bantuan Hidup Dasar (BHD). Cardio Pulmonary Resusitation (CPR) atau yang biasa disebut Resusitasi Jantung Paru (RJP) adalah sekumpulan intervensi yang bertujuan untuk mengembalikan dan mempertahankan fungsi vital organ pada korban henti jantung dan henti nafas. Intervensi ini terdiri dari pemberian kompresi dada dan bantuan nafas. ${ }^{8}$ Resusitasi jantung paru (RJP) yang efektif adalah dengan menggunakan kompresi dan dilanjutkan dengan ventilasi. ${ }^{9}$ Komponen penting dalam melakukan RJP adalah kedalaman kompresi, kecepatan kompresi, ventilasi, return of spontaneus circulation (ROSC) dan meminimalisas interupsi. ${ }^{10}$ Hal ini sesuai dengan penelitian dari fatmawati mengenai pengaruh edukasi Basic Life Support terhadap tingkat pengetahuan mahasiswa Program Studi Ilmu Keperawatan didapatkan hasil bahwa ada pengaruh di antara keduanya.

Berdasarkan hasil wawancara kepada 8 anggota brimob golongan I tentang tindakan Resusitasi Jantung Paru (RJP), didapatkan hasil bahwa tidak ada satupun brimob yang mengerti dan memahami tentang bantuan hidup dasar khsusnya tentang prosedur dari Resusitasi Jantung Paru (RJP). Mereka mengatakan bahwa mereka tidak mengetahui cara untuk memberikan resisitasi jantung paru, merka juga mengatakan bahwa apabila menemui orang dengan henti jantung mereka tidak mampu memberikan bantuan hidup dasar Resusitasi Jantung Paru (RJP) karena mereka tidak mengetahui apa yang harus dilakukan, salah satu tindakan yang dapat mereka lakukan yaitu meminta bantuan kepada petugas kesehatan

Tujuan Penelitian ini adalah untuk mengetahui tingkat Efektifitas simulasi Resusitasi Jantung Paru terhadap kemampuan penatalaksanaan Resusitasi Jantung Paru Anggota Brimob Di Kompi 1 Batalion C Pelopor Satbrimob POLDA Jatim.

\section{Metode}

Desain penelitian adalah pra eksperimental dengan pendekatan one-group pre test post test. Populasi semua anggota Brimob di Kompi 1 Batalyon C Pelopor Satbrimob Polda Jatim sebanyak 100 orang Responden diambil dengan teknik accidental sampling.,di dapatkan sampel sebanyak 25 responden. Varibel independen pemberian simulasi Resusitasi Jantung Paru, variabel dependen kemampuan penatalaksanaan Resusitasi Jantung Paru, kemudian dianalisis dengan uji statistik Wilcoxon.

\section{Hasil}

Karakteristik Subyek

Tabel 1. Karakteristik responden dalam penelitian ini meliputi usia, pendidikan dan kemampuan resusitasi jantung paru sebelum dan sesudah dilakukan simulasi.

\begin{tabular}{llcc}
\hline No & Karakteristik & $\mathbf{\Sigma n}$ & $\mathbf{\Sigma \%}$ \\
\hline 1 & Usia (th) & \multicolumn{1}{c}{} \\
& $<25$ & 7 & 28 \\
& $25-35$ & 12 & 48 \\
& $>35$ & 6 & 24 \\
\hline 2 & Pendidikan & \multicolumn{2}{c}{} \\
& SMA & 21 & 84 \\
& Sarjana & 4 & 16 \\
\hline 3 & Kemampuan resusitasi jantung \\
& paru sebelum dilakukan simulasi \\
& Kurang & 25 & 100 \\
& Cukup & 0 & 0 \\
& Baik & 0 & 0 \\
\hline 4 & Kemampuan resusitasi jantung \\
& paru setelah dilakukan simulasi \\
& Kurang & 0 & 0 \\
& Cukup & 3 & 12 \\
& Baik & 22 & 88 \\
\hline & Total & $\mathbf{2 5}$ & $\mathbf{1 0 0}$ \\
\hline
\end{tabular}

Berdasarkan dari tabel 1 diatas diketahui bahwa dari total 25 responden yang berusia 25-35 tahun yaitu sebanyak 12 responden (48\%), berpendidikan SMA yaitu sebanyak 21 responden (84\%), memiliki kemampuan dengan kategori kurang dalam melakukan resusitasi jantung paru sebelum dilakukan simulasi yaitu sebanyak 25 (100\%) 
responden dan sesudah dilakukan simulasi memiliki kemampuan dengan kategori baik yaitu sebanyak 22 (88\%) responden.

Tabel 2. Efektivitas simulasi RJP terhadap kemampuan penatalaksanaan RJP

\begin{tabular}{|c|c|c|}
\hline \multicolumn{3}{|c|}{ Test Statistics $^{b}$} \\
\hline & \multicolumn{2}{|c|}{$\begin{array}{l}\text { kemampuan_sesudah - ke- } \\
\text { mampuan_sebelum }\end{array}$} \\
\hline Z & & $-4.772^{\mathrm{a}}$ \\
\hline $\begin{array}{l}\text { Asymp. Sig. (2- } \\
\text { tailed) }\end{array}$ & & .000 \\
\hline \multicolumn{3}{|c|}{ a. Based on negative ranks. } \\
\hline b. Wilcoxon Sign & Ranks Test & \\
\hline
\end{tabular}

Berdasarkan hasil uji statistik yang telah dilakukan diketahui bahwa nilai $p=$ 0,000 sehingga H1 diterima yang artinya ada simulasi Resusitasi Jantung Paru (RJP) efektif terhadap kemampuan penatalaksanaan Resusitasi Jantung Paru (RJP) Anggota Brimob di Kompi 1 Batalyon C Pelopor Satbrimob Polda Jatim.

\section{Pembahasan}

\section{Kemampuan Anggota Brimob Melakukan Resusitasi Jantung Paru Sebelum Dilakukan Simulasi}

Seluruh Anggota Brimob Di Kompi 1 Batalyon C Pelopor Satbrimob POLDA Jatim memiliki kemampuan dengan kategori kurang dalam melakukan resusitasi jantung paru sebelum dilakukan simulasi yaitu sebanyak 25 $(100 \%)$ responden dari total 25 responden. Menurut International Organization for Migration (IOM) simulasi adalah metode pembelajaran atau pendampingan yang memperagakkan sesuatu dalam bentuk tiruan yang mirip dengan keadaan yang sesungguhnya. Metode ini menggunakan gambaran dari suatu situasi yang nyata tanpa harus mengalaminya. Simulasi memberikan latihan dalam situasi tiruan.

Menurut Mais mengatakan, bahwa tingkat kemampuan yang ada pada setiap orang dipengaruhi oleh pengetahuan yang dimilki yang diterima atau ditangkap melalui pancaindera, semakin banyak pancaindera yang digunakan, maka semakin banyak dan semakin jelas pula pengertian atau pengetahuan yang diperoleh. ${ }^{13}$ Penelitian yang dilakukan Ikhsan Sodiq dengan judul gaya hidup dan penyakit jantung koroner menyatakan bahwa lemak berkontribusi terhadap terjadinya aterosklerosis pada pasien dengan gangguan jantung.

Hasil penelitian menjukan bahwa seluruh responden dalam penelitian ini memiliki kemampuan yang kurang dalam melakukan Resusitasi Jantung Paru sebelum dilakukan simulasi Resusitasi Jantung Paru, yang dimaksud dengan kemampuan kurang dalam melakukan Resusitasi Jantung Paru yaitu responden hanya mengetahui bahwa apabila menemukan korban dengan henti napas dan henti jantung tindakan yang diberikan yaitu resusitasi Resusitasi Jantung Paru sedangkan langkah-langkah dari tindakan Resusitasi Jantung Paru responden tidak mengetahuinya. Kurangnya kemampuan responden dalam melakukan Resusitasi Jantung Paru disebabkan karena responden yang digunakan dalam penelitian ini yaitu responden yang belum pernah mengikuti pelatihan tentang Resusitasi Jantung Paru dan responden tidak memiliki latar belakang dari kesehatan, serta responden hanya mendengarkan informasi tentang resusitasi jantung paru dari media sosial seperti televisi dan internet sehingga pengetahuan responden tentang Resusitasi Jantung Paru masih kurang yang menyebabkan kemampuan responden dalam melakukan Resusitasi Jantung Paru masih kurang.

\section{Kemampuan Anggota Brimob Melakukan Resusitasi Jantung Paru Setelah Dilakukan Simulasi}

Hampir seluruh Anggota Brimob Di Kompi 1 Batalyon C Pelopor Satbrimob POLDA Jatim memiliki kemampuan dengan kategori baik dalam melakukan resusitasi jantung paru setelah dilakukan simulasi yaitu sebanyak $22(88,0 \%)$ responden dari total 25 responden.Penelitian ini sejalan dengan teori yang jelaskan bahwa untuk mendorong sebuah pelayanan kesehatan publik yang berkualitas, masyarakat harus memiliki banyak informasi dan aktif terlibat di dalamnya sehingga mereka 
mampu untuk melakukan pencegahan sejak dini terhadap timbulnya suatu penyakit. Adapun untuk petugas kesehatan tetap melakukan pendampingan dan pemantauan secara rutin pula kegiatan health education tersebut.

Hasil penelitian menunjukan hampir seluruh Anggota Brimob Di Kompi 1 Batalyon C Pelopor Satbrimob POLDA Jatim memiliki kemampuan dengan kategori baik dalam melakukan resusitasi jantung paru setelah dilakukan simulasi Resusitasi Jantung Paru. Adapun tindakan yang disimulasikan yaitu cara mengamankan lokasi kejadian, mengkaji respon korban, cek nadi carotis, langkah-langkah melakukan resusitasitasi jantung paru serta cara memberikan posisi recovery kepada korban. Hasil penelitian menunjukan bahwa kemampuan responden meningkat setelah dilakukan simulasi, dan berdasarkan pengamatan yang dilakukan oleh peneliti sebagaian besar responden mampu melakukan prosedur resusitasi jantung paru dengan baik dan benar setelah dilakukan simulasi.

\section{Efektifitas Simulasi Resusitasi Jantung Paru Terhadap Kemampuan Penatalaksanaan Resusitasi Jantung Paru Anggota Brimob}

Berdasarkan hasil uji statistik yang telah dilakukan diketahui bahwa nilai p-value $=0,000$ sehingga $\mathrm{H} 1$ diterima yang artinya simulasi Resusitasi Jantung Paru (RJP) efektif terhadap kemampuan penatalaksanaan Resusitasi Jantung Paru (RJP) Anggota Brimob di Kompi 1 Batalyon C Pelopor Satbrimob Polda Jatim. Hasil tabulasi silang kemampuan sebelum dan sesudah simulasi menunjukan hampir seluruh Anggota Brimob Di Kompi 1 Batalyon C Pelopor Satbrimob POLDA Jatim yang memiliki kemampuan dengan kategori kurang melakukan resusitasi jantung paru sebelum diberikan simulasi memiliki kemampuan dengan kategori baik sesudah dilakukan simulasi yaitu sebanyak $22(88,0 \%)$ responden dari total 25 responden.

Pertolongan yang tepat dalam menangani kasus kegawatdaruratan dalam hal ini yaitu cardiac arrest adalah Basic Life Support atau yang dikenal dengan Bantuan Hidup Dasar (BHD). Cardio Pulmonary Resusitation (CPR) atau yang biasa disebut Resusitasi Jantung Paru (RJP) adalah sekumpulan intervensi yang bertujuan untuk mengembalikan dan mempertahankan fungsi vital organ pada korban henti jantung dan henti nafas. Intervensi ini terdiri dari pemberian kompresi dada dan bantuan nafas. ${ }^{8}$ Resusitasi jantung paru bermanfaat untuk menjaga oksigenasi darah dan perfusi jaringan yang bertujuan untuk memperbaiki jantung sehingga dapat meningkatkan kesempatan hidup pasien. Komponen penting dalam melakukan RJP adalah kedalaman kompresi, kecepatan kompresi, ventilasi, return of spontaneus circulation (ROSC) dan meminimalisas iinterupsi.

Berdasarkan fakta dan teori yang telah dibahas peneliti berpendapat hasil peneliti yang ditemukan dilapangan sejalan dengan teori yang telah dijelaskan diatas, dimana simulasi resusitasi jantung paru efektif terhadap peningkatan kemampuan anggota brimob dalam melakukan resusitasi jantung paru, hal ini disebabkan karena dengan diberikan simulasi maka anggota brimob akan terpapar dengan informasi mengenai resusitasi jantung paru yang menyebabkan kemampuan anggota brimob dalam melakukan resusitasi jantung paru meningkat mejadi lebih baik karena anggota brimob sudah menguasai langkahlngkah resusitasi jantung paru dan hal apa saja yang harus dilakukan ketika ingin memberikan pertolongan pertama pada saat menemukan korban dengan henti jantung.

\section{Kesimpulan}

Dari hasil penelitian yang telah dilakukan oleh peneliti maka didapatkan hasil usia responden yang paling banyak berusia antara 2535 tahun dengan pendidikan SMA dengan kemampuan sebelum diberikan pengetahuan tentang resusitasi adalah sangat kurang. Setelah dilakukan uji statistik didapatkan bahwa setelah dilakukan penelitian didapatkan kemampuan yang baik dalam pelaksanaan RJP sehingga sesuai dengan uji statistik bivariat yang menyatakan terdapat efektivitas simulasi RJP terhadap kemampuan penatalaksanaan RJP.

\section{Daftar Pustaka}


1. Pusbankes 118. Penanggulangan Penderita Gawat Darurat (PPGD). Edisi X. Yogyakarta: Tim Pusbankes 118 - PERSI DIY; 2013.

2. Sartono. Buku Panduan BTCLS_Sartono. Jakarta: CV Sagung Seto; 2011. 217 p.

3. Kemenkes RI. Profil Kesehatan Indonesia tahun 2013. 2014;

4. Kemenkes RI. Laporan Hasil Riset Kesehatan Dasar (Riskesdas) Indonesia. Badan Penelitian dan Pengembangan Kesehatan Kemenkes RI. 2013;

5. Ulfah M, Soetoprawiro K, Garna YPP, Prasetyo AD. Sistem Pertanggung jawaban hukum kepolisianNegara Republik Indonesia secara organisasional maupun personal. 2013;

6. Priyantoko G, Daerah K, Utara S. Penerapan diskresi kepolisian dalam penanganan unjuk rasa. 2016;I(9):109-36.

7. Robert H. Eckel. Wiley. Metabolic risk for cardiovascular disease edited. Blackwell Publishing; 2011.

8. Hardisman hardisman. Gawat Darurat Medis Praktis. Yogyakarta: Gosyen Publishing; 2014.

9. Kaliammah Ganthikumar. Indikasi dan Keterampilan Resusitasi Jantung Paru (RJP). Intisari Sains Medis [Internet]. 2016;6:58-64. Available from: http://intisarisainsmedis.weebly.com/

10. Infinger AE, Vandeventer S, Studnek JR. Introduction of performance coaching during cardiopulmonary resuscitation improves compression depth and time to defibrillation in out-of-hospital cardiac arrest \&. Resuscitation [Internet]. 2014;85(12):1752-8. Available from:

http://dx.doi.org/10.1016/j.resuscitation.2014.
09.016

11. Fatmawati BR, Suprayitna M, Prihatin K. Efektifitas Edukasi Basic Life Support dengan Media Audiovisual dan Praktik Terhadap Tingkat Pengetahuan dan Keterampilan Mahasiswa Program Studi Ilmu Keperawatan Jenjang D . III Stikes Yarsi Mataram Tahun 2018. 2018;7:6-12.

12. Susanti Budi Pratiwi. Peran simulasi bencana terhadap kesiapsiagaan siswa kelas VII dalam menghadapi bencana banjir di SMP Negeri 1 Grogol Kecamatan Grogol Kabupaten Sukohardjo. 2013;

13. Mais PR, Mulyadi mulyadi, Lolong J. Pengaruh penyuluhan bahaya gunung berapi terhadap kesiapsiagaan siswa SMP Kristen Kakaskasen kota Tomohon menghadapi bencana gunung berapi. ejoural Keperawatan (e-Kep). 2015;3.

14. Kardinah, Sri Indiyastuti. Pelibatan Masyarakat dalam deteksi dini kanker Payudara. YAPPIKA. 2007;

15. Sodik, Ikhsan. "Gaya Hidup Pasien Penyakit Jantung Koroner." Jurnal Ilmiah Ilmu Keperawatan Indonesia 7.04 (2017): 332-338.

16. Muniarti S, Herlina S, Test WS, Taruna K. Pengaruh simulasi pelatihan bantuan hidup dasar (BHD)terhadap motivasi dan skill Resusitasi Jantung Paru (RJP)pada karang taruna RW 06 Kampung Utan Kelurahan Krukut. J Keperawatan Widya Gantari Indones. 2019;3(2). 